\title{
Origin and SEM analysis of aerosols in the high mountain of Tenerife (Canary Islands)
}

\author{
Juan D. Delgado ${ }^{1,2 *}$, Omaira E. García ${ }^{3}$, Ana M. Díaz ${ }^{3}$, Juan P. Díaz ${ }^{3}$, Francisco J. Expósito ${ }^{3}$, \\ Emilio Cuevas ${ }^{4}$, Xavier Querol ${ }^{5}$, Andrés Alastuey ${ }^{5}$, Sonia Castillo ${ }^{5}$

\footnotetext{
${ }^{1}$ Área de Ecología, Departamento de Sistemas Físicos, Químicos y Naturales, Universidad Pablo de Olavide, Seville, Spain;

*Corresponding Author: jddelgar@upo.es;

${ }^{2}$ Instituto Universitario de Enfermedades Tropicales y Salud Pública de Canarias, La Laguna, Tenerife, Canary Islands, Spain;

${ }^{3}$ Departamento de Física Básica, Universidad de La Laguna, E-38206 La Laguna, Tenerife, Canary Islands, Spain;

${ }_{4}^{4}$ Izaña Observatory, Instituto Nacional de Meteorología, INM, Santa Cruz de Tenerife, Canary Islands, Spain;

${ }^{5}$ Institute of Environmental Assessment and Water Research (IDAEA), CSIC, Barcelona, Spain.
}

Received 18 May 2010; revised 21 June 2010; accepted 24 June 2010.

\section{ABSTRACT}

Focusing on aerosolized matter of relevance to respiratory health, a major public health issue worldwide, we studied mineral and biological aerosol (bioaerosol) composition (TSP and $\mathrm{PM}_{2.5}$ ) and geographical origins during dust intrusions in the Canary Islands. Seven days' backward trajectories were assessed daily during March 2004 with the ends of back trajectories being the sampling station of Izaña (high mountain, 2360 $\mathrm{m}$ a.s.l. at the Cañadas del Teide National Park, Tenerife island), a free troposphere site allowing characterization of dust with low influence of other pollutant sources. Scanning electron microscopy (SEM) was used to survey major types of airborne particles in the dust plumes. Control, non-intrusion conditions correspond to Atlantic oceanic middle troposphere (OMT) air masses. Of the 14 samples taken, 1 corresponded to a control (clear atmosphere conditions), and the remaining 13 to dust intrusions, with the following sources: African Dust; EAM: mixture of Europe, Africa and Oceanic; MaA: maritime aerosols. Of the air masses, $79 \%$ were directly transported to the islands from Africa, and an increase of African dust events was detected when comparing with a 52-year previous data sequence. Quartz microcristals and aggregates of quartz and platy clay were the dominant minerals identified, with marine salt and gypsum also present. Freshwater diatom tests (from two Aulacoseira species) represented the most important biogenic aerosols, although fungi and pollen were also detected. The diverse and complex mixture of respirable particles in large quantities in airborne dust, especially from nearby Sahara and from the Sahelian region, is of maximum interest for airway pathology in the Canaries, including the highly visited highlands in Tenerife.

Keywords: Allergens; Bioaerosols; Diatoms; High altitude; Desert dust intrusion; Public health;

Scanning electron microscopy

\section{INTRODUCTION}

The dispersal of abiotic and biological aerosols (bioaerosols), has a growing interest in interdisciplinary research comprising epidemiology, public health and atmospheric physics. This is due to the great capacity of air masses to transport both viable organisms and inorganic dust to remote areas, where they transform local tropospheric conditions [1] and may affect human health [2]. The cell-carrying capacity of wind, long-range and high frequency transport of dust masses, aggravate the effects of seasonal peaks in local allergens through additive and synergic effects. The transport of dust might involve carrying up to 10.000 bacterial cells per gram of soil from some desert areas [3]. For example, diatoms are a large fraction of dust carried from fresh waters of the Saharo-Sahelian areas and Eurasia to remote areas such as the Caribbean [4]. Charles Darwin, on his 1845 voyage aboard the surveying ship H.M.S. Beagle, collected African dust in the Atlantic and microscopically detected the occurrence of diatoms in the dust. This same historic dust has been recently analyzed to find at least 16 different viable bacterial lineages and 2 fungal isolates [5].

Although the global amount of species of airborne pathogens is not so far clearly defined, several hundreds 
of bacterial lineages, fungi and viruses can be involved in allergy, asthma and pulmonary affections, and airborne dust is a vehicle for them [6-10]. Inhaled atmospheric aerosols of any origin can be associated with a number of diseases and disorders, namely allergic airways disease (or asthma), rhinitis and rhinosinusitis, alveolitis or allergic parenchymal disease, airways or parenchymal infections, atypical thoracic pain, anxiety disorders, cardiopathy, and meningitis, among others [11-14].

The Canary Islands lay $96 \mathrm{~km}$ off the west of the largest dust source on Earth, the Sahara desert ( $>9$ million square kilometres), being comprised within the "dustbelt", where the atmospheric dust concentration is inherently very high [15]. Dust transport to the Canaries causes several-fold increase over the standard levels of particulate matter over the islands [1,16-20]. Although studies relating desert dust to "airborne" diseases in the Canary Islands are scant, dust events reach the archipelago with a high frequency, being associated with augmented prevalence, morbidity and mortality [12]. There are precedents in other regions, such as the Caribbean Sea where increase of frequency in African dust episodes reaching Barbados were associated to a seventeen-fold increase in asthma between 1973 and 1996 [21-23]. In Gran Canaria and Tenerife, type and frequency of asthma symptoms have been analyzed in a large population sample, and climatic conditions have been invoked to explain high prevalences [24].
In this paper we study aerosols from African dust intrusions at a high altitude ecosystem in Tenerife, Canarian archipelago. Specific health effects of minerogenic dust and bioaerosols have not been studied so far in the Canary Islands, and this task is difficult to approach without recognizing the type of particles involved. We thus aimed to identify and survey, through scanning electronic microscopy (SEM) analysis, the biological and mineral aerosol particles transported with dust during intrusions of African air masses and from other origins to the Canary Islands. Imaging characterization of dust particles could give us explicit information on aerosol types in relation with complementary data on origin and travelling time of air masses. We related the dust events with the air-mass origin, tracing back the dust trajectories to assess source areas. Our primary concern was on aerosolized particles with a potential interest in public health that are transported with dust plumes from Africa to the Canary Islands.

\section{METHODS}

\subsection{Study Area}

We studied air samples searching for biogenic particles (bioaerosols) during a non-intrusion episode ("clean atmosphere") and during dust invasions to Tenerife, the largest and more densely populated and visited island of this group (Table 1). Our sampling was focused on the

Table 1. Characteristics of air samples from filters taken at the high mountain station of Izaña in Tenerife.

\begin{tabular}{|c|c|c|c|c|c|c|c|c|}
\hline \multirow{3}{*}{$\begin{array}{c}\begin{array}{c}\text { Particle sampler } \\
\text { type }\end{array} \\
\text { PM2.5 }\end{array}$} & \multirow{2}{*}{\multicolumn{2}{|c|}{$\begin{array}{l}\text { Hour (GMT) and initial } \\
\text { sampling date }\end{array}$}} & \multirow{2}{*}{\multicolumn{2}{|c|}{$\begin{array}{l}\text { Hour (GMT) and } \\
\text { final sampling date }\end{array}$}} & \multirow{3}{*}{$\begin{array}{c}\begin{array}{c}\text { Cycle volume } \\
\left(\mathrm{m}^{3}\right)\end{array} \\
731\end{array}$} & \multirow{3}{*}{$\begin{array}{c}\begin{array}{c}\text { African dust } \\
\text { outbreaks }\end{array} \\
+\end{array}$} & \multicolumn{2}{|c|}{$\begin{array}{c}\text { Back } \\
\text { Trajectory }\end{array}$} \\
\hline & & & & & & & \multirow{2}{*}{$\begin{array}{c}\text { Initial sampling } \\
\text { EAM }\end{array}$} & \multirow{2}{*}{$\begin{array}{c}\text { Final sampling } \\
\text { EAM }\end{array}$} \\
\hline & $14: 44$ & 03/03/04 & $14: 50$ & $04 / 03 / 04$ & & & & \\
\hline PM2.5 & $14: 58$ & $04 / 03 / 04$ & $15: 40$ & $05 / 03 / 04$ & 506 & + & EAM & EAM \\
\hline PM2.5 & $12: 22$ & $17 / 03 / 04$ & $12: 26$ & $18 / 03 / 04$ & 731 & + & AfD & AfD \\
\hline PM2.5 & 11:05 & $22 / 03 / 04$ & $11: 40$ & $23 / 03 / 04$ & 733 & + & AfD & AfD \\
\hline PM2.5 & $10: 12$ & $04 / 04 / 04$ & $15: 35$ & $05 / 04 / 04$ & 732 & + & $\mathrm{MaA}$ & $\mathrm{MaA}$ \\
\hline TSP & $15: 48$ & 03/03/04 & $15: 55$ & $04 / 03 / 04$ & 732 & + & EAM & EAM \\
\hline TSP & $16: 10$ & $04 / 03 / 04$ & $16: 20$ & $05 / 03 / 04$ & 731 & + & EAM & EAM \\
\hline TSP & $16: 30$ & $05 / 03 / 04$ & $16: 45$ & $06 / 03 / 04$ & 731 & + & EAM & EAM \\
\hline TSP & $12: 26$ & $11 / 03 / 04$ & $15: 10$ & $12 / 03 / 04$ & 731 & - (control) & OMT & OMT \\
\hline TSP & $12: 13$ & $17 / 03 / 04$ & $12: 17$ & $18 / 03 / 04$ & 731 & + & AfD & AfD \\
\hline TSP & $12: 23$ & $18 / 03 / 04$ & $13: 30$ & $19 / 03 / 04$ & 732 & + & AfD & EAM \\
\hline TSP & 11:00 & $22 / 03 / 04$ & $11: 35$ & $23 / 03 / 04$ & 731 & + & AfD & AfD \\
\hline TSP & $11: 45$ & $23 / 03 / 04$ & $12: 20$ & $24 / 03 / 04$ & 731 & + & AfD & AfD \\
\hline TSP & 10:05 & $04 / 04 / 04$ & $13: 40$ & $05 / 04 / 04$ & 732 & + & $\mathrm{MaA}$ & $\mathrm{MaA}$ \\
\hline
\end{tabular}

Trajectory codes: OMT: Atlantic Oceanic Middle Troposphere; AfD: African Dust; EAM: mixture of Europe, Africa and Oceanic origins; MaA: maritime aerosols. 
high mountain scrub, at the Teide National Park (free troposphere, over the stable inversion layer, which is found between 1000-1500 m), at the facilities of the Instituto Nacional de Meteorología (Izaña Observatory, 16 ${ }^{\circ} 29^{\prime} 58^{\prime \prime} \mathrm{W} ; 28^{\circ} 18^{\prime} 32^{\prime \prime} \mathrm{N} ; 2360 \mathrm{~m}$ a.s.1.) (Figure 1).

The Izaña site is located above a sharp temperature inversion between 500 and $1500 \mathrm{~m}$, thus remaining relatively apart from the contamination foci of the low areas and human settlements [25]. At Izaña, the characterization of African dust is possible with low interference of other pollutant sources [26]. The dust transport is strongly seasonal, occurring near the surface in the cold season (October to March) and above two kilometres altitude in the warm season (April to September) [27,28]. We centred the sampling effort in March-April 2004. Annual distribution of particulate matter at low areas in the Canary Islands peaks in winter and shows a minimum in summer, whereas in the Tenerife high mountain, the maximum dust incomes occur in summer. Nevertheless dust episodes are also commonly detected in springtime in both levels [19,27,28]).

\subsection{Dust Trajectories and Origins}

To assess the origin of the aerosols, seven days backward trajectories were calculated daily at 00 and 12 UTC during March 2004 with HYSPLIT-4 model (Draxler and Hess, 1997 in [27]). The end point of the back trajectories was the Izaña station. Physical-chemical aero- sol properties can be related with the origin and trajectory of the aerosol-laden air masses. Díaz [27] and Díaz et al. [28] developed a methodology to characterize the source-transport paths of the aerosol over this region using multivariate clustering analysis. The back trajectories classification is based on the contribution of the main aerosol sources, considering the geographical regions, the residence time in these sectors and the altitude of the air mass during the evolution towards the island. With this technique, clusters of back trajectories can be found for different levels of transport and origins of the air masses [28].

\subsection{Dust SEM Analysis}

TSP (Total Suspended Particles) and $\mathrm{PM}_{2.5}$ (Particulate Matter with 2.5 micrometers diameter or smaller) were sampled simultaneously on quartz glass filters (Schleicher and Schuell, QF20), with high volume samplers MCV CAV-A / M $\left(30 \mathrm{~m}^{3} / \mathrm{h}\right)$. Samplers operated for $24 \mathrm{~h}$ periods from 03 / 03 / 04 until 05 / 04 / 04, and completed 14 samples (Table 1). We separated part of the filters for scanning electron microscope (SEM) analysis. A small section $\left(<1 \mathrm{~cm}^{2}\right)$ of each filter was cut and glued onto an aluminium stub and processed for SEM. Complementarily, another section of the filter was gently pressed on an adhesive carbon conductive tab to transfer the filter content to the preparation, then the tab was glued to the stub and processed for SEM. Preparations

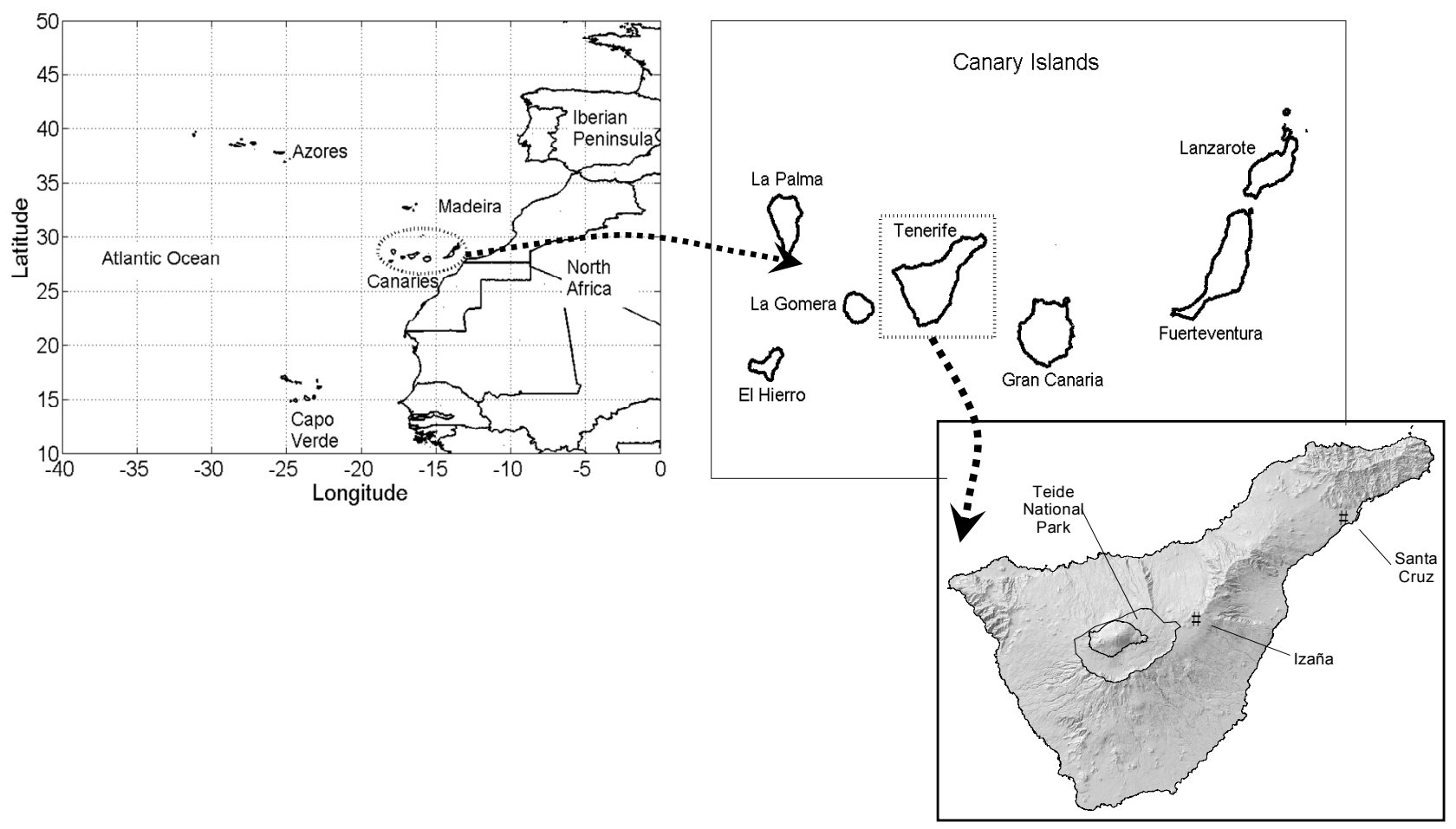

Figure 1. Study area and sampling stations. 
were observed and photographed in a JEOL JSM 6300 electron microscope. We resolved the elemental composition of some particles with X-ray electron probe microanalysis (EDX) (OXFORD 6699) of selected SEM samples. The system operated at $20 \mathrm{kV}$ (operation range: $0.2-30 \mathrm{kV}$ ) with a maximum resolution of $3.5 \mathrm{~nm}$.

\section{RESULTS}

\subsection{Dust Trajectories and Origins}

Clusters of back trajectories found were: 1) representtative of Atlantic oceanic middle troposphere (OMT); 2) air masses originated in the African continent (AfD); 3) mixture of aerosols from at least two of these sources: Europe, Africa and Ocean (EAM); 4) air masses with high load of maritime aerosols (MaA). The average frequencies of occurrence of these clusters on March over a 52 year period (1948-2004) were 17\% AfD, 24\% EAM, $40 \%$ OMT and $19 \%$ MaA.

Mean altitude for trajectories ending at Izaña was $2970.85 \mathrm{~m}$ (range: 0-8119.5 m) in March 2004. The back trajectories analysis for Tenerife for that month showed that air masses were $30 \%$ AfD, 24\% EAM, 24\% OMT and $22 \% \mathrm{MaA}$. These values revealed an increase in frequency of African dust events (cluster AfD) of 13\% at the high mountain site compared with the average value of the 52-year period. In particular, of the 14 samples obtained at Izaña (Table 1), 13 corresponded to mineral dust conditions, where the $79 \%$ of the air masses were directly transported from the African continent (43\% AfD and 36\% EAM), whereas the remaining two represent maritime air masses with presence of dust particles. This last situation is observed most likely during the spring-summer period at Izaña [28], where the air masses cross areas with a high concentration of dust due to a Sahara-Sahel outbreak occurred in previous days. As exemplified in Figure 2 (upper panel), the air mass in cluster AfD progressed at low altitudes while crossing the eastern Sahara desert (particularly between 0 and $15^{\circ}$ E) and then gained altitude approaching the Atlas range, finally reaching the end point in the Tenerife high mountain at $2360 \mathrm{~m}$. Furthermore, given that a $24 \mathrm{~h}$ sampling schedule was applied, the possibility of ascending air masses transporting coastal material up to the summit at Izaña station can not be disregarded [26].

\subsection{SEM Survey of Dust Particulate Matter}

In our SEM samples, most abiotic and biological or biogenic particles are within the respirable size range. Aerosols presenting a wide size range (including $\mathrm{PM}_{2.5}$ and $\mathrm{PM}_{10}$ ) were quartz and clay grains, gypsum rods and halite. Crustal aerosols appeared clustered, which increased average lateral dimension of particles. The main bio-

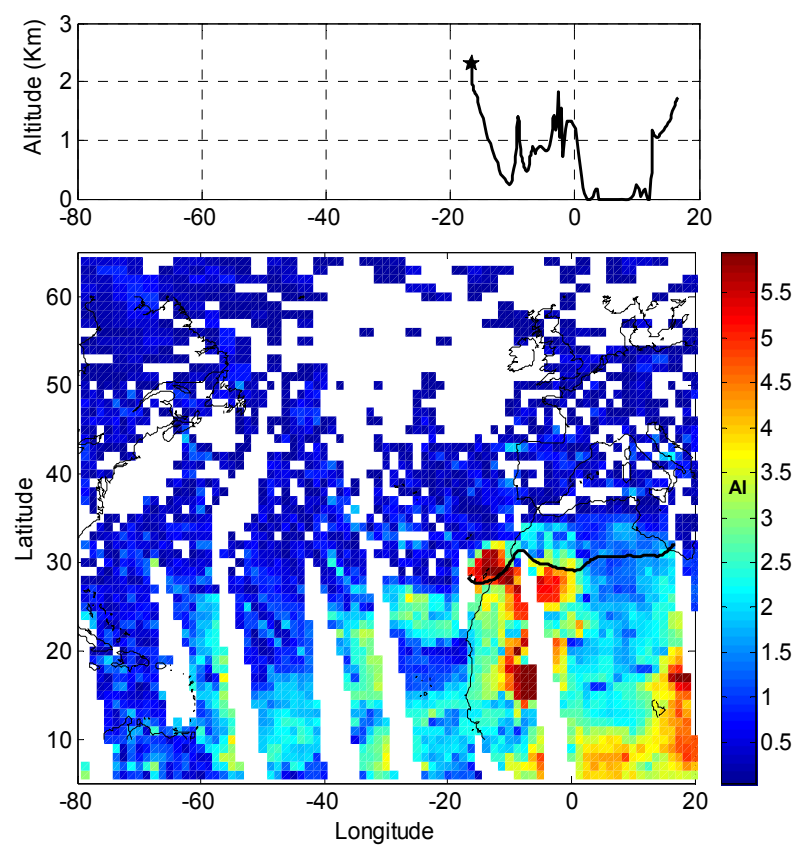

Figure 2. Values of the TOMS AI (Total Ozone Mapping Spectrometer Aerosol Index) for a back trajectory of 24 / 03 / 2004 (black line, below graphic) of African mineral dust estimated for Izaña (Tenerife, Canary Islands). The TOMS aerosol index is a relative measure of the amount of aerosol particles absorbing radiation in the atmosphere. The vertical altitude- longitude cross section of the trajectory is shown in the upper panel (maximum at ca. $2400 \mathrm{~m}$ a.s.1.). The white arrow points the geographic evolution of the air mass from left to right. The colour scale is adimensional and depicts the TOMS AI.

aerosols found here (diatoms) belong to the $\mathrm{PM}_{10}$ fraction, although a large amount of fragmented thecae were within the $\mathrm{PM}_{2.5}$ class; pollen grains and one fungal conidium were within $\mathrm{PM}_{10}$.

\subsection{Aerosols of Biotic Origin}

We made only an overview of major aerosol types transported with dust to the Canaries, and we did not quantify the concentration of airborne species. The most abundant biological remains identified in our SEM samples for African dust episodes were diatom siliceous tests (Figure 3). Two species of the genus Aulacoseira Thwaites (1848) (formerly Melosira), were identified: $A$. granulata (Ehrenb.) Simonsen 1979 and A. islandica (O. Müller) Simonsen (Bacillariophyta). Apart from diatom remains, other biogenic material was difficult to observe in SEM preparations, where the mineral fraction dominated. We identified only one fungal taxon, most probably Alternaria sp., as determined from a clavate conidium, showing the loculi under an irregular surface (Figure 3 (A)).

Pollen grains were found by SEM but species could 

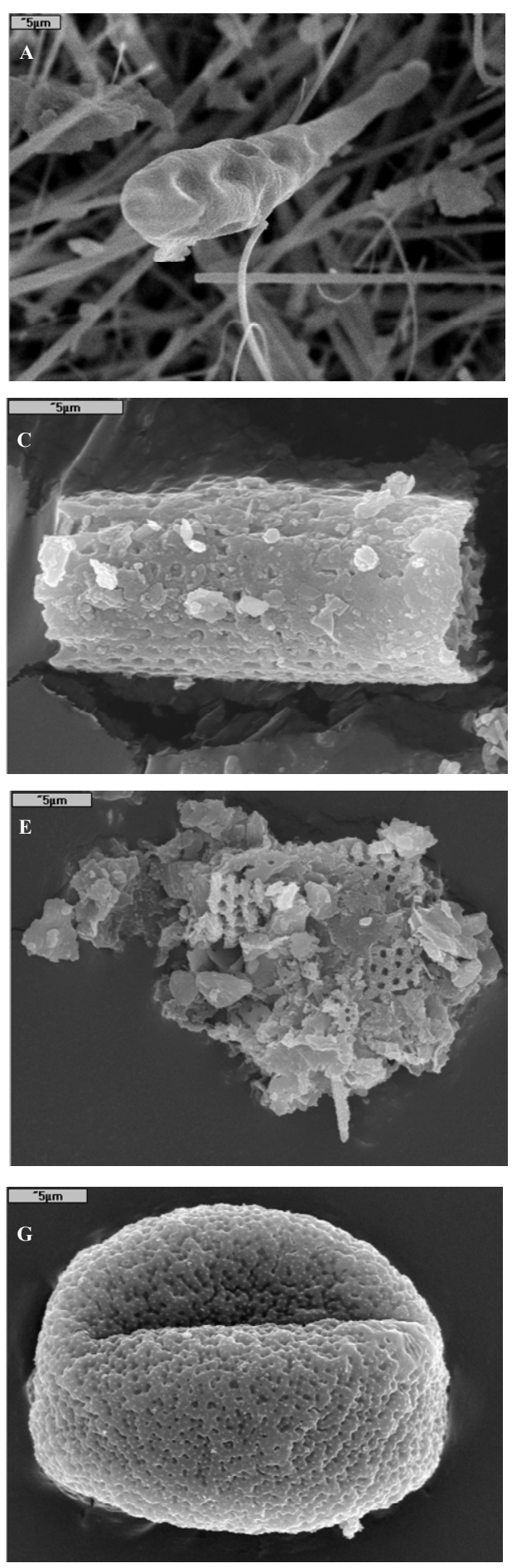
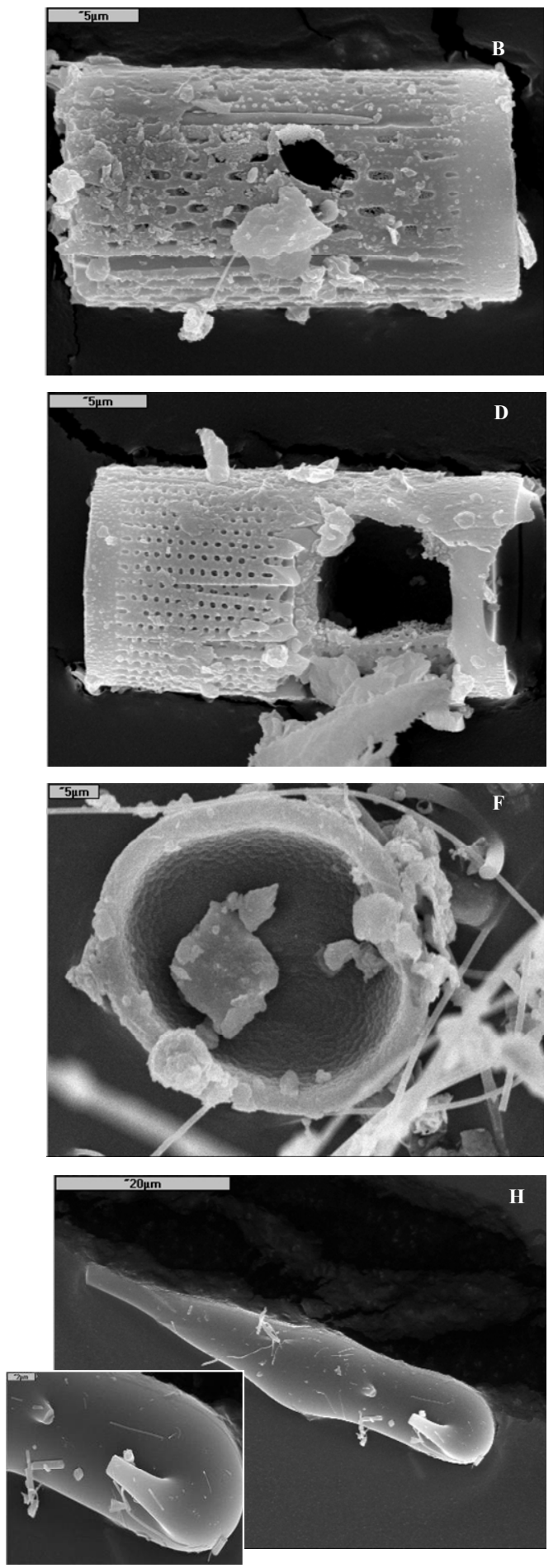

Figure 3. SEM photographs of TSP and $\mathrm{PM}_{2.5}$, biogenic particulate matter or bioaerosols identified in dust filters from Tenerife (Canary Islands) during African dust intrusions. All samples from Las Cañadas (high mountain site), excepting F (Santa Cruz, coastal city). (A): Typically club-shaped Conidium of ascomycotan fungi (Alternaria sp., a cause of allergic fungal sinusitis). (B)-(D): Siliceous tests of freshwater diatoms ((B) and (C): Aulacoseira granulata; (D): A. islandica), heavily eroded and worn due to the transport process. (E): Conglomerate of diatom test remains (presumably Aulacoseira spp.) with platy clay particles. (F): undetermined pollen grain, cross-section, containing mineral particles (Santa Cruz). (G): pollen grain, undetermined species. (H): fragmentary spicule-like particle (inset: magnification), origin (either abiotic or biological) and composition uncertain. 
not be assigned (Figure 3(G)). Pollen was very rare in filters, which operated during the early spring season when flowering period was not at its peak in the Tenerife high mountain. We failed to identify bacterial cells in filter preparations examined with SEM.

\subsection{Aerosols of Abiotic Origin}

Filters from the control day ("clean troposphere") showed a very different aspect when compared with filters from dust events (Figures 4(A),4(B)), the latter being concealed with a dense mineral-biomineral matrix (Figure 4(C)). The abiotic particulate aerosols identified individually included clay grades and quartz microcristals (isolated or aggregated) of crustal origin (from AfD cluster), and gypsum rods $\left(\mathrm{CaSO}_{4}\right)$. Halite, cubic and cube-octahedra crystals of sea salt $(\mathrm{NaCl})$ were obtained from the OMT cluster correspondent to clear atmospheric conditions and incidence of marine aerosol reaching the high mountain area (compare with [26]).

Quartz $\left(\mathrm{SiO}_{2}\right)$ microcristals (particles from $<10 \mu \mathrm{m}$ to $<2 \mu \mathrm{m}$ ) formed the dominant or background material in our filters during dust intrusions (Figure 4). Aerosols transported from the Sahara desert are enriched in clay material due to a high residence time in atmosphere caused by a smaller particle size and laminar habit; these clay grade grains are transported as particles of silt size forming aggregates $[29,30]$ (Figure 4).

\section{DISCUSSION}

As suggested by our filter samples from different origins, Aulacoseira diatom thecae compound the dominant biogenic aerosol, and quartz is the dominant mineral fraction, which also formed up to $60 \%$ of dust material in a study from Gran Canaria [31].

The diatoms identified are dominant taxa in fresh waters from N and NW Africa, and can be found throughout the Palaearctic [32]. A. granulata has been recorded in the Arctic probably transported from Siberia [33]. Both $A$. islandica and $A$. granulata are typical of eutrophized and alkaline waters. As far as we know, these species have not been deemed as pathogenic to humans; on the contrary, they are used as bioindicators of freshwater quality in most studies. They can be transported as viable cells through the ocean, and their importance in the windblown diatom fraction decrease with increasing distance from the African continent [4]. The aeolian transport of diatoms and phytolyths from continental fresh water deposits in the Sahara and Sahel [4,34] should be investigated to assess relative contribution to high incidence of environmental airway diseases in the Canaries. We are not aware of detailed clinic studies relating natural (desert) diatom dust with respiratory diseases. Fur- thermore, concentrations of airborne diatom particles from African deserts and professional exposure to diatom dust are not comparable [35]. Diatoms transported with the dust plumes to the Canaries augment the overall silica content of the aerosols, and silicosis caused by noncrystalline forms of silica have not only occupational but environmental etiology [36]. On the contrary, non-industrial silicosis (known as "desert lung") has been reported decades ago from autopsy of Bedouine lung tissue, showing high amounts of silica dust of respirable size [37]. More study cases of non-industrial lung or environmental silicosis, have been reported for regions chronically exposed to desert dust (i.e. Himalaya [38]).

The Tenerife highland (>2000 $\mathrm{m}$ a.s.l.) is not a populated area, but it receives $>4$ million visitors/year, the most visited volcanic area of the world after Mount Fuji, Japan. There is evidence that symptoms of asthma in lowland patients improve with therapy of high-elevation stays $[39,40]$; however, episodic but severe dust events may imply additional health risks given the extreme conditions at these altitudes for such long permanencies (moderate hypoxia, high aridity of this area and increased sun radiation exposure, among other stressors). Origin and type of air mass and aerosol load can be predicted and used to establish and prevent potential interactions with respiratory disease in susceptible visitors to the island's National Park.

Particles of different sizes have different ability to penetrate the pulmonary system and reach the lung parenchyma [41]. Modelling of aerosol inhalation schematize the stratification of particle deposition along the human airways depending on their aerodynamic diameter [42]. Particulate matter $(\mathrm{PM})<10 \mu \mathrm{m}\left(\mathrm{PM}_{10}\right)$ penetrate the tracheobronchial region; increased deposition in the oropharynx occurs with particles larger than $6 \mu \mathrm{m}$, whereas central airway deposition peaks within the 4-6 $\mu \mathrm{m}$ range. Particles like those in Figures 4(B), 4(D) or 4 (I) would be able to reach the central airways. PM between 2-4 $\mu \mathrm{m}\left(\mathrm{PM}_{2.5}\right)$ reach the alveolar cavities (i.e. lung periphery), where their damage is greater due to higher reactivity [42]. Particles like the one depicted in Figure 4(K) seem of potential interest in this range.

Although a great proportion of diatom remains are within or above the $\mathrm{PM}_{10}$ fraction (particulate matter 10 micrometers in diameter), thereby being potentially retained by the trachea and bronchia, a great amount of test fragments are within the $\mathrm{PM}_{2.5}$ fraction, and thus could reach the lung alveolar system [35]. In addition, the role of diatom thecae as carriers of particles of health interest (e.g. bacteria, viruses, fungal or protozoan spores or cists, pollen) can be important, since: a) these remains co-dominate, along with quartz mineral, in many of the dust events of North African origin, and b) 

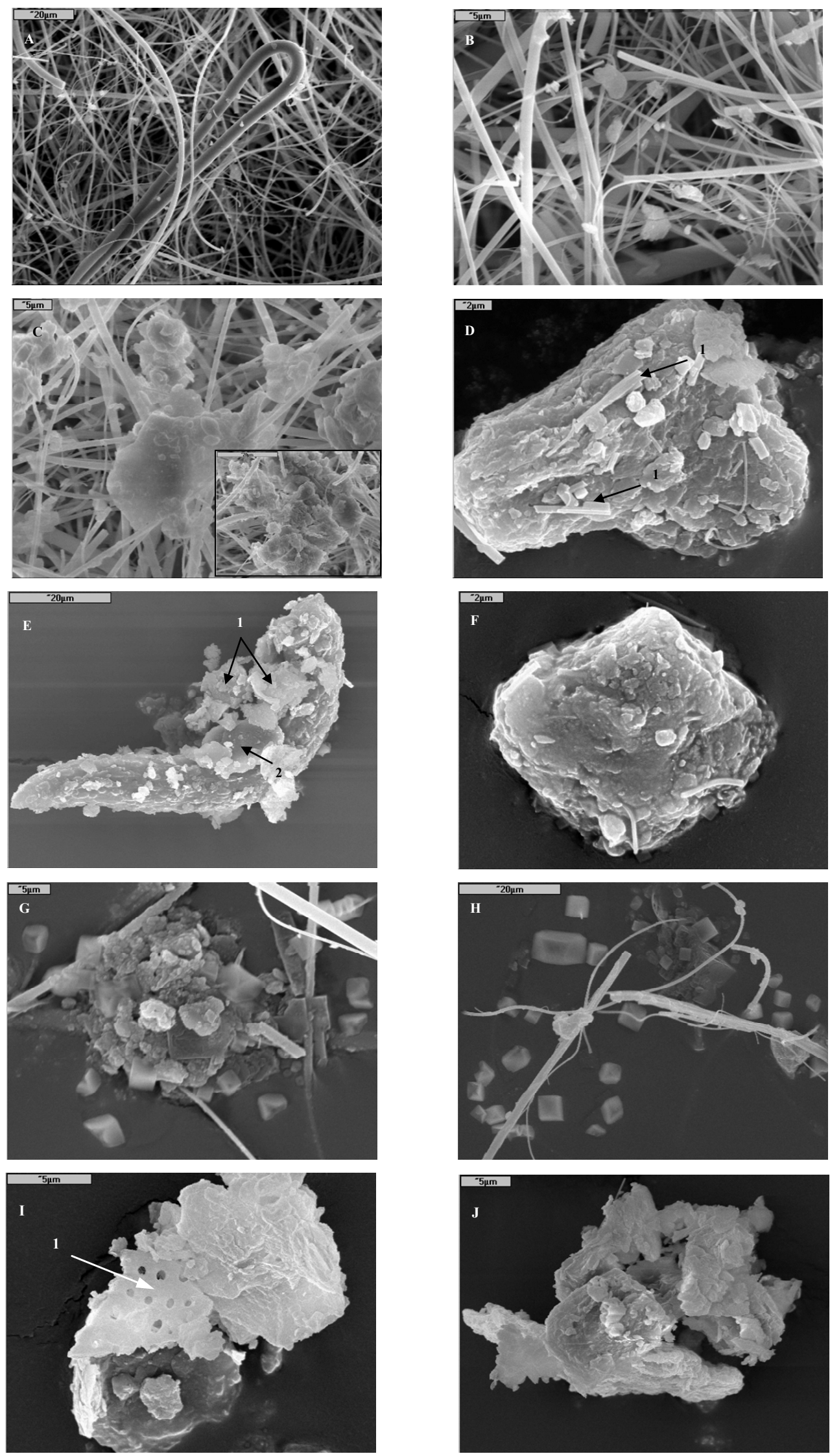


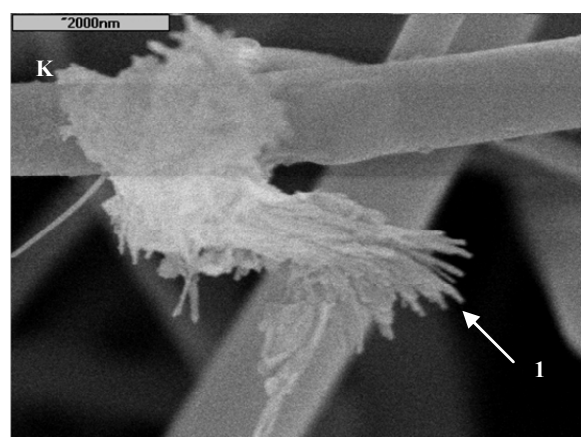

Figure 4. SEM photographs of TSP and $\mathrm{PM}_{2.5}$, mineral aerosols of crustal, marine and anthropogenic origin identified in dust filters from Tenerife (Canary Islands) during an African dust intrusion. (A)(B): two general views of a relatively clean filter with few mineral particles (without African dust) from Izaña. (C): filters with dense platy clay microcrystals typical of a dust intrusion (Santa Cruz). (D): Agglomeration of clay on carbon adhesive film (EDX: Si, Al, K, Ca, Fe, Na, Mg) (Izaña); 1: elongate rectangles on the aggregate surface are gypsum rods (EDX: Ca, S, O). (E)-(F): clay microcristals; 1: clay aggregates; 2: flat and rounded quartz particles adhered (Izaña). (G)-(H): halite (EDX: $\mathrm{Na}, \mathrm{Cl}$ ), clusters of cubic crystals from marine aerosol (Santa Cruz). (I)-(J): conglomerates of quartz clay grades with diatom test fragments of laminar habit (1); (K): fibrous particle of unknown origin around the $2 \mu \mathrm{m}$ size range attached to filter; note the "fringed" end (1).

due to their structural complexity, large adsorption surface and cavities for shelter of diverse particles, and lateral dimension.

We found only a fungal remain in our dust samples. However, fungal species linked to respiratory disease are surprisingly frequent from desert areas [6]. Some deserts next to urban areas behaved as differentiated sources of Basydiomycotan fungi [43]. Kellogg et al. [10] detected Alternaria, Cladosporium and Aspergillus in dust samples from Mali. Cladosporium was also isolated from African dust in the Virgin Islands (Caribbean) [7]. Prospero et al. [44] isolated more than 20 fungal taxa from North African dust in Barbados, finding low percentages of Alternaria. With Cladosporium, Alternaria is one of the most abundant spore-forming fungi in dry and warm regions such as the subtropical Canary Islands [6]. $\mathrm{Al}$ ternaria was also a very frequent bioaerosol in a study at mid elevation on Tenerife [45]. In other dry climates (e.g. Phoenix, Arizona), A. alternata and A. raphani has been detected in $\mathrm{PM}_{10}$ from desert neighbouring urban areas [43], and Glikson et al. [46] found that fungal spores were predominant over other bioaerosols such as pollen in Brisbane (Australia). We failed to find other fungal remains through SEM, a surprising result since we expected a higher importance of this type of particles during dust events, judging from literature. However, we isolated and cultivated other common allergenic fungi (Aspergillus, Penicillium and Cladosporium) which were not detected by SEM from the same filter samples (unpublished data).

Apart from plant pathogen, Alternaria is a cosmopolitan, saprophytic soil fungus comprising several species pathogenic for immunocompromised hosts $[47,48]$.
A. alternata causes environmental allergic alveolitis, and for many authors it is the most important fungi in allergy causation, especially in Mediterranean areas [49]. Allergic fungal sinusitis is due to finely dispersed fungal spores in air, and $56-95 \%$ percent of patients diagnosed with chronic rhinosinusitis presented fungus in nasal secretions $[50,51]$. We should investigate frequency and concentration of fungal spores in this insular region and if causes for high prevalence of allergies in areas affected by dust intrusions might be attributed to airborne fungal species.

Around $20 \%$ of the human population of the Canaries suffers from allergy or allergy-related diseases [52]. However, prevalence of diseases such as asthma or allergies has not been paid enough attention regarding associations with climatic factors, climate change or influence of atmospheric phenomena such as Saharo-Sahelian dust episodes on the archipelago [24]. The complex mixture of particles of respirable size identified by SEM in this study may play a role in sensitizing and thus preparing the road for other "opportunistic" airway diseases. Processes of aerosol particles deposition and effects in the airways depend on particle size and form, and respiratory conditions [35], but the mechanisms by which both mineral aerosols and bioaerosols act in the airway pathologies are poorly comprised.

In populated areas, mixtures amongst particulate matter of different origins are common during dust intrusions, as revealed by our SEM analysis. In many instances, allergens invade the respiratory tract in or on a different particle, and it is today clear that exposure to an allergen on or within a carrier pollutant can substantially enhance its allergenic potential $[53,54]$. Many of the 
aerosol types overviewed here can incorporate additional pollutants from the atmosphere, and in case of bioaerosols, surface proteins can be altered and then released into the respiratory system. Synergies between anthropogenic aerosols and bioaerosols also deserve attention. Diatom tests, quartz and gypsum fiber-like particles mix to form aggregates, and pollen grains can transport those and other mineral particles (Figures 4(B)-4(F),4(J)). Important synergies between bioaerosols (mostly pollen, fungi and soil bacteria, but perhaps also viruses) and other atmospheric pollutants (i.e. NOx, VOCs_-volatile organic compounds - ozone, tobacco smoke) have been reported in relation with increasing asthma prevalence in urban areas [46]. Pollen secrete eicosanoid-like molecules (i.e. leukotriene-like) which act signaling in immunity and inflammation, and such releasing is favoured by contact of pollen with gases from traffic exhaust and petrol industry [54].

The study of the origin of the air mass through back trajectory would allow knowing the potential of remote subtropical and tropical areas for issuing other disease vectors in dust plumes to the Canary Islands and other places. This tool should be integrated along with quantitative and qualitative aerosol characterization in the creation of prevention nets $[12,55]$. Attention should be paid to candidate disease vectors that can be predicted, through tracing of backward trajectories, to reach the islands with dust intrusions in the next future. In fact, nearly $80 \%$ of the air masses reaching the islands have a direct North African origin. SEM analysis is useful as a complementary tool in the morphological identification of new particle types or combinations of particles of interest in disease causation [56]. Moreover, exploratory biopsy of the respiratory mucosa through SEM analysis would prove useful in identifying PM types and linking them as causal factors with atmospheric dust PM. Nevertheless, molecular and clinical characterization of the active substances associated to aerosols is a critical and unavoidable step for prevention of dust mass impact on human health [54]. In the Caribbean, relationship between asthma attendance peaks and African dust intrusions have previously been revealed [23]. For the Canary Islands, where African dust intrusions exert their effects before reaching the Caribbean, the studies dealing with problems posed by dust intrusions on public health remain anecdotic, whereas effective control of dust effects on human population is a major sanitary goal [12].

\section{CONCLUSIONS}

Aeolian dust reaching the high altitude areas of the Tenerife island has a larger contribution of North African air masses, and is formed by a structurally complex mixture of biogenic and abiogenic particles, of respirable size and contrasting morphology; we found that the diatom test fraction is qualitatively relevant (along with the dominant, background quartz fraction), whereas other biogenic fractions such as pollen or fungi are more scarce, or difficult to resolve, at least by means of SEM, and at these elevations within the island. Increasing aridity periods, irregular and torrential rains, changes in vegetation cover and desertification would affect the aerosol load (both biogenic and abiogenic in origin) received by these subtropical islands as dust intrusion events increase in frequency $[16,17,57]$.

\section{ACKNOWLEDGEMENTS}

We thank Juan Luis González Álvarez (SEGAI facilities, ULL) and Debora Gómez for assistance with SEM. Prof. Dr. Óscar Romero (Universitaet Bremen, Germany) gently identified diatoms. We acknowledge to the MEC (Ministry of Education and Science, Spain) and F.E.D.E.R. founds (E.U.) for the economical support of the following projects: CGL2005-03428-C04-02, CGL2007-66477-C02-02/CLI, CGL200804740 and PI042005/033. Finally, the authors wish to express their appreciation to the operators of Izaña Atmospheric Observatory for their help on running the instruments.

\section{REFERENCES}

[1] Hernández, F., Alonso-Pérez, S., Hernández-Armasa, J., Cuevas, E., Karlsson, L. and Romero-Campos, P.M. (2005) Influence of major African dust intrusions on the ${ }^{137} \mathrm{Cs}$ and ${ }^{40} \mathrm{~K}$ activities in the lower atmosphere at the Island of Tenerife. Atmospheric Environment, 39, 41114118.

[2] Main, C.E. (2003) Aerobiological, ecological, and health linkages. Environment International 2003, 29, 347-349.

[3] Kuhlman, K.R., Allenbach, L.B., Ball, C.L., Fusco, W.G., La Duc, M.T., Kuhlman, G.M., Anderson, R.C., Erickson, I.K., Stuecker, T., Benardini, J. and Crawford, R.L. (2005) Enumeration, isolation, and characterization of ultraviolet (UV-C) resistant bacteria from rock varnish in the Whipple Mountains, California. Icarus, 174, 585-595.

[4] Romero, O.E., Lange, C.B., Swap, R.J. and Wefer, G. (1999) Eolian-transported freshwater diatoms and phytoliths across the equatorial Atlantic record temporal changes in Saharan dust transport patterns. Journal of Geophysical Research, 104(C2), 3211-3222.

[5] Gorbushina, A.A., Kort, R., Schulte, A., Lazarus, D., Schnetger, B., Brumsack, H.-J., Broughton, W.-J. and Favet, J. (2007) Life in Darwin's dust: Intercontinental transport and survival of microbes in the nineteenth century. Environmental Microbiology, 9, 2911-2922.

[6] Lacey, J. (1991) Aerobiology and health: The role of airborne fungal spores in respiratory disease. In: Hawksworth, D.L. Ed., Frontiers in Mycology, C. A. B. International, Wallingford, 157-185.

[7] Griffin, D.W., Garrison, V.H., Herman, J.R. and Shinn, E.A. (2001a) African desert dust in the Caribbean atmosphere: Microbiology and public health. Aerobiologia, 17, 203-213. 
[8] Griffin, D.W., Kellogg, D.A. and Shinn, E.A. (2001b) Dust in the wind: Long range transport of dust in the atmosphere and its implications for global public and ecosystem health. Global Change \& Human Health, 2, 20-33.

[9] Griffin, D.W., Westphal, D.L. and Gray, M.A. (2006) Airborne microorganisms in the African desert dust corridor over the mid-Atlantic ridge, Ocean Drilling Program, Leg 209. Aerobiologia, 22, 211-226.

[10] Kellogg, C.A., Griffin, D.W., Garrison, V.H., Peak, K., Royall, N., Smith, R.R. and Shinn, E.A. (2004) Characterization of aerosolized bacteria and fungi from desert dust events in Mali, West Africa. Aerobiologia, 20, 99-110.

[11] Salvaggio, J.E. (1994) Inhaled particles and respiratory disease. The Journal of Allergy and Clinical Immunology, 94, 304-309.

[12] García Carrasco, J., Hernández Vázquez, A., Blasco de la Fuente, A., Rodríguez Hernández, B.C., Rancaño Gila, E. and Núñez Díaz, S. (2001) Invasión de viento sahariano y su impacto en la asistencia sanitaria urgente. Emergencias, 13, 372-376.

[13] Pope, C.A., Burnett, R.T., Thun, M.J., Calle, E.E., Krewski, D., Ito, K. and Thurston, G.D. (2002) Lung cancer, cardiopulmonary mortality, and long-term exposure to fine particulate air pollution. JAMA, 287, 1132-1141.

[14] Lee, J.-T., Son, J.-Y. and Cho, Y.-S. (2007) A comparison of mortality related to urban air particles between periods with Asian dust days and without Asian dust days in Seoul, Korea, 2000-2004. Environmental Research, 105, 409-413.

[15] Prospero, J.M. and Lamb, J.P. (2003) African droughts and dust transport to the Caribbean: Climate change and implications. Science, 302, 1024-1027.

[16] Viana, M., Querol, X., Alastuey, A., Cuevas, E. and Rodríguez, S. (2002) Influence of African dust on the levels of atmospheric particulates in the Canary Islands air quality network. Atmospheric Environment, 36, 58615875.

[17] Viana, M., Querol, X., Alastuey, A., Ballester, F., Llop, S., Esplugues, A., Fernández-Patier, R., García dos Santos, S. and Herce, M.D. (2008) Characterising exposure to PM aerosols for an epidemiological study. Atmospheric Environment, 42, 1552-1568.

[18] Criado, C. and Dorta P. (2003) An unusual "blood rain" over the Canary Islands (Spain). The storm of January 1999. Journal of Arid Environments, 55, 765-783.

[19] Alonso-Pérez, S., Cuevas, E., Querol, X., Viana, M. and Guerra, J.C. (2007) Impact of the Saharan dust outbreaks on the ambient levels of total suspended particles (TSP) in the marine boundary layer (MBL) of the Subtropical Eastern North Atlantic Ocean. Atmospheric Environment, 41, 9468-9480.

[20] Querol, X., Alastuey, A., Moreno, T., Vian, M.M., Castillo, S., Pey, J., Rodríguez, S., Artiñano, B., Salvador, P., Sánchez M., García, S., Herce, M.D., Fernández-Patier, R., Moreno-Grau, S., Minguillón, M.C., Monfort, E., Sanz, M.J., Palomo-Marín, R., Pinilla-Gil, E., Cuevas E., De La Rosa, J. and Sánchez, A. (2008) Spatial and temporal variations in airborne particulate matter (PM10 and PM2.5) across Spain 1999-2005. Atmospheric Environment, 42, 3964-3979.

[21] Prospero, J.M. (1999a) Long-term measurements of the transport of African mineral dust to the south-eastern
United States: Implications for regional air quality. Journal of Geophysical Research, 104, 917-927.

[22] Prospero, J.M. (1999b) Assessing the impact of advected African dust on air quality and health in the Eastern United States. Human and Ecological Risk Assessment, 5, 471-479.

[23] Prospero, J.M., Blades, E., Naidu, R., Mathison, G., Thani, H. and Lavoie, M.C. (2008) Relationship between African dust carried in the Atlantic trade winds and surges in pediatric asthma attendances in the Caribbean. International Journal of Biometeorology, 52, 823-832.

[24] Julià Serdà, G., Cabrera Navarro, P., Acosta Fernández, O., Martín Pérez, P., Batista Martín, J., Alamo Santana, F., Rodríguez de Castro, F. and Antó Boqué, J.M. (2005) High prevalence of asthma symptoms in the Canary Islands: climatic influence? Journal of Asthma, 42, 507-511.

[25] Rodríguez, S. (1999) Comparación de la variaciones de ozono superficial asociadas a procesos de transporte sobre y bajo la inversión temperatura subtropical en Tenerife. Unpublished Thesis, Universidad de La Laguna, Santa Cruz de Tenerife, Spain.

[26] Alastuey, A., Querol, X., Castillo, S., Escudero, M., Avila, A., Cuevas, E., Torres, C., Romero, P.M., Expósito, F., García, O.E., Díaz, J.P., van Dingenen, R. and Putaud, J.P. (2005) Characterisation of TSP and PM2.5 at Izaña and Sta. Cruz de Tenerife (Canary Islands, Spain) during a Saharan dust episode (July 2002). Atmospheric Environment, 39, 4715-4728.

[27] Díaz, A.M. (2006) Caracterización de los aerosoles atmosféricos y su influencia en los niveles de radiación UV en la región de Canarias. Ph.D. Thesis, University of La Laguna, Tenerife, Spain.

[28] Díaz, A.M., Díaz, J.P., Expósito, F.J., Hernández-Leal, P.A., Savoie, D. and Querol, X. (2006) Air masses and aerosols chemical components in the free troposphere at the Subtropical Northeast Atlantic region. Journal of Atmospheric Chemistry, 53, 63-90.

[29] Pósfai, M. and Molnár, Á. (2000) Aerosol particles in the troposphere: A mineralogical introduction. In: Vaughan, D.J. and Wogelius, R.A., Eds., Environmental Mineralogy, Eötvös University Press, Budapest, 197-252.

[30] Thomas, D., Potter, T.D. and Colman, B.R. (2003) Handbook of weather, climate, and water. John Wiley \& Sons, Hoboken.

[31] Gelado, M.D., Dorta, P., Hernández, J.J., Collado, C., Rodríguez, M.J., Cardona, P. and Siruela, V. (2004) Characterisation of African dust outbreaks in Gran Canaria (Canary Islands). Geophysical Research Abstracts, 6, 05227.

[32] Gómez, N., Riera, J.L. and Sabater, S. (1995) Ecology and morphological variability of Aulacoseira granulata (Bacillariophyceae) in Spanish reservoirs. Journal of Plankton Research, 17, 1-16.

[33] Darby, D.A., Burckle, L.H. and Clark D.L. (1974) Airborne dust on the Arctic ice pack, its composition and fallout rate. Earth and Planetary Science Letters, 24, 166-172.

[34] Lange, C.B., Romero, O.E., Wefer, G. and Gabric, A. (1998) Offshore influence of coastal upwelling off Mauritania, NW Africa, as recorded by diatoms in sediment traps at $2195 \mathrm{~m}$ water depth. Deep-Sea Research, 45, 9851013.

[35] Derbyshire, E. (2007) Natural minerogenic dust and human health. AMBIO: A Journal of the Human Environ- 
ment, 36, 73-77.

[36] Kusaka, Y., Hering, K. and Parker, J. (2005) International classification of HRCT for occupational and environmental respiratory diseases. Springer-Verlag, Tokyo.

[37] Bar-Ziv, J. and Goldberg, G.M. (1974) Simple siliceous pneumoconiosis in Negev Bedouins. Arch Environ Health, 29, 121.

[38] Norboo, T., Angchuk, P.T., Yahya, M., Kamat, S.R., Pooley, F.D., Corrin, B., Kerr, I.H., Bruce, N. and Ball, K.P. (1991) Silicosis in a Himalayan village population: Role of environmental dust. Thorax, 46, 341-343.

[39] Simon, H., Grotzer, M., Nikolaizik, W., Blaser, K. and Schóni, M. (1994) High altitude climate therapy reduces peripheral blood $\mathrm{T}$ lymphocyte activation, eosinophilia, and bronchial obstruction in children with house-dust mite allergic asthma. Pediatric Pulmonology, 17, 304-311.

[40] Schultze-Werninghaus, G. (2006) Should asthma management include sojourns at high altitude? Chemical Immunology and Allergy, 91, 16-29.

[41] Silson, J.E. (1950) Dust inhalation in relation to pulmonary disease. Chest, 18, 562-573.

[42] Mitchell, J.P. and Nagel, M.W. (2004) Particle size analysis of aerosols from medicinal inhalers. KONA, 22, 32-65.

[43] Boreson, J., Dillner, A.M. and Peccia, J. (2004) Correlating bioaerosol load with $\mathrm{PM}_{2.5}$ and $\mathrm{PM}_{10}$ concentrations: A comparison between natural desert and urban-fringe aerosols. Atmospheric Environment, 38, 6029-6041.

[44] Prospero, J.M., Blades, E., Mathison, G. and Naidu, R. (2005) Interhemispheric transport of viable fungi and bacteria from Africa to the Caribbean with soil dust. Aerobiologia, 21, 1-19.

[45] La Serna, I. and Domínguez, M.D. (2003) Pólenes y esporas aerovagantes en Canarias: Incidencia en alergias. Colección Materiales Didácticos Universitarios, Serie Botánica 1, SPULL, Tenerife.

[46] Glikson, M., Rutherford, S., Simpson, R., Mitchell, C. and Yago, A. (1995) The microscopic and submicron components of atmospheric particulates occurring during high asthma periods in Brisbane, Queensland, Australia. Atmospheric Environment, 29, 549-562.

[47] Morrison, V.A. and Weisdorf, D.J. (1993) Alternaria: A sinonasal pathogen of immunocompromised hosts. Clinical Infectious Diseases, 16, 265-270.

[48] Hospenthal, D.R. and Bennett, J.E. (2000) Miscellaneous fungi and Prototheca. In: Mandell, G.L., Bennet, J.E. and
Dolin, R. Eds., Principles and practice of infectious diseases, 5th Edition, Livingstone, Philadelphia, 2772-2780.

[49] D'Amato, G., Chatzigeorgiou, G., Corsico, R., Gioulekas, D., Jäger, L., Jäger, S., Kontou-Fili, K., Kouridakis, S., Liccardi, G., Meriggi, A., Palma-Carlos, A., PalmaCarlos, M.L., Pagan, A., Parmiani, S., Puccinelli, P., Russo, M., Spieksma, F.T., Torricelli, R. and Wuthrich, B. (1997) Evaluation of the prevalence of skin prick test positivity to Alternaria and Cladosporium in patients with suspected respiratory allergy. EEACI Position Paper. Allergy, 52, 711-716.

[50] Lebowitz, R.A., Waltzman, M.N., Jacobs, J.B., Pearlman, A. and Tierno, P.M. (2002) Isolation of fungi by standard laboratory methods in patients with chronic rhinosinusitis. Laryngoscope, 112, 2189-2191.

[51] Braun, H., Buzina, W., Freudenschuss, K., Beham, A. and Stammberger, H. (2003) "Eosinophilic fungal Rhinosinusitis": A common disorder in Europe? Laryngoscope, 113, 264-269.

[52] Gaig, P., Ferrer, M., Muñoz-Lejarazu, D., Lleonart, R., García-Abujeta, J.L., Caballero, T., Rodríguez, A., Echechipia, S., Martínez-Cocera, C., Domínguez, F.J., Gonzalo, M.A. and Olona, M. (2004) Prevalencia de alergia en la población adulta española. Alergología e Inmunología Clínica, 19, 68-74.

[53] Salvaggio, J.E. and O’Neil, C.E. (1992) Pathogenetic mechanisms in occupational hypersensitivity states. Immunology and Allergy Clinics of North America, 4, 711729.

[54] Behrendt, H., Krämer, U., Schäfer, T., Kasche, A., Eberlein-König, B., Darsow, U. and Ring, J. (2001) A research concept to study the role of environmental pollutants in allergy. Allergy and Clinical Immunology International, 13, 122-128.

[55] Mastalerz, M., Glikson, M. and Simpson, R.W. (1998) Analysis of atmospheric particulate matter; application of optical and selected geochemical techniques. International Journal of Coal Geology, 37, 143-155.

[56] Wittmaack, K., Wehnes, H., Heinzmann, U. and Agerer, R. (2005) An overview on bioaerosols viewed by scanning electron microscopy. Science of the Total Environment, 346, 244-255.

[57] Rodríguez, S., Querol, X., Alastuey, A., Kallos, G. and Kakaliagou, O. (2001) Saharan dust contributions to PM10 and TSP levels in Southern and Eastern Spain. Atmospheric Environment, 35, 2433-2447. 